\title{
Marine research in the Latitudinal Gradient Project along Victoria Land, Antarctica*
}

\author{
PAUL ARTHUR BERKMAN ${ }^{1}$, RICCARDO CATTANEO-VIETTI, \\ MARIACHIARA CHIANTORE ${ }^{2}$, CLIVE HOWARD-WILLIAMS ${ }^{3}$, VONDA CUMMINGS ${ }^{3}$ \\ and RIKK KVITEK ${ }^{4}$ \\ ${ }^{1}$ Bren School of Environmental Science and Management, University of California, Santa Barbara, CA 93106 USA. E- \\ mail: berkman@bren.ucsb.edu \\ ${ }^{2}$ DIPTERIS, Università di Genova, I-16132 Genoa, Italy. \\ ${ }^{3}$ National Institute of Water and Atmospheric Research, Riccarton, Christchurch, New Zealand. \\ ${ }^{4}$ Earth Systems Science and Policy, California State University Monterey Bay, Seaside, CA 93955 USA.
}

\begin{abstract}
SUMMARY: This paper describes the conceptual framework of the Latitudinal Gradient Project that is being implemented by the New Zealand, Italian and United States Antarctic programmes along Victoria Land, Antarctica, from $72^{\circ} \mathrm{S}$ to $86^{\circ} \mathrm{S}$. The purpose of this interdisciplinary research project is to assess the dynamics and coupling of marine and terrestrial ecosystems in relation to global climate variability. Preliminary data about the research cruises from the R/V "Italica" and R/V "Tangaroa" along the Victoria Land Coast in 2004 are presented. As a global climate barometer, this research along Victoria Land provides a unique framework for assessing latitudinal shifts in 'sentinel' environmental transition zones, where climate changes have an amplified impact on the phases of water.
\end{abstract}

Keywords: Latitudinal Gradient Project, Victoria Land, Antarctic, global climate change, interdisciplinary cooperation.

RESUMEN: INVESTIGACIONES MARINAS A LO LARGO DE VICTORIA LAND. - Este trabajo describe el marco conceptual del proyecto "Gradiente latitudinal" que ha sido implementado por los programas antárticos de Nueva Zelanda, Italia y EE.UU. a lo largo de Victoria Land (Antártida), $72^{\circ} \mathrm{S}-86^{\circ} \mathrm{S}$ ). El objetivo de este proyecto es evaluar la dinámica y el acoplamiento de ecosistemas marinos y terrestres con relación a los cambios climáticos globales. Se presenta información preliminar acerca de los cruceros científicos de los buques R/V "Italica" y "Tangaroa" a lo largo de la costa de Victoria Land en el año 2004. Como un barómetro climático global, esta investigación provee un marco de trabajo único para observar y evaluar cambios latitudinales en zonas de transición medioambiental, donde los cambios climáticos tienen un impacto amplificado en las fases del agua.

Palabras clave: Proyecto Gradiente Latitudinal, Victoria Land, Antártida, cambio climático global, cooperación interdisciplinaria.

\section{INTRODUCTION}

Coastal zones of continents and oceans-where terrestrial and marine ecosystems interact-are regions of high biological and physical diversity, which are generally heavily utilized by human pop-

*Received December 15, 2004. Accepted June 8, 2005. ulations. Distinguishing natural and anthropogenic impacts in coastal zones and throughout the Earth system is a major challenge of science in our global society (Berkman, 2002). The Antarctic coastal zone, while utilized by humans to a limited extent, is among the most pristine regions on the planet for unambiguously assessing such global changes. The purpose of this paper is to review the results of the 


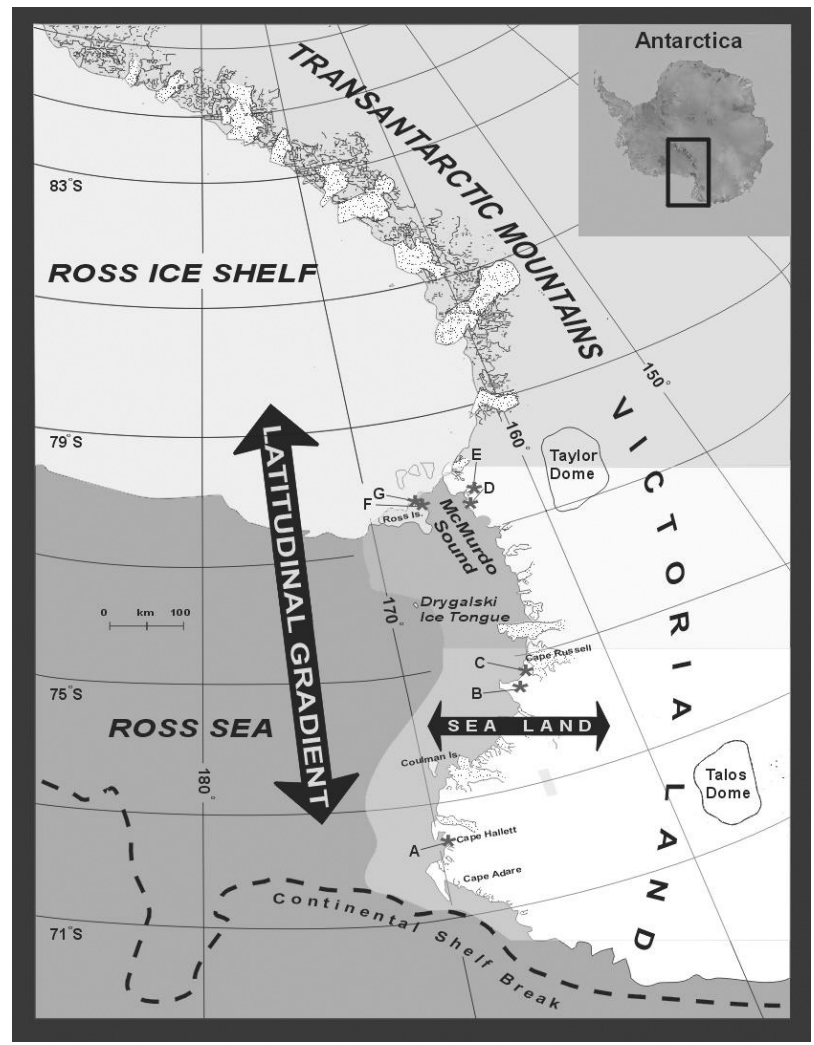

FIG. 1. - Spatial context of the Latitudinal Gradient Project along Victoria Land, Antarctica, from approximately $72^{\circ} \mathrm{S}$ to $86^{\circ} \mathrm{S}$ in the Ross Sea region. The principal research zones, which are recognized to have decreasing water vapour exchange between the ocean and land, from north to south are the: Open-Water Zone (south of Cape Adare to the Drygalski Ice Tongue in the Terra Nova Bay region); Fast-Ice Zone (south of the Drygalski Ice Tongue to McMurdo Sound and the edge of the Ross Ice Shelf; and Ice-Shelf Zone (south of the Ross Ice Shelf edge). National research stations, which represent the logistic centres for research along Victoria Land, are from north to south: A Cape Hallett (New Zealand and United States, summer only); B Gondwana (Germany, unoccupied); C Mario Zuchelli Station (Italy, summer only); D Marble Point (United States, summer only); E McMurdo Long-Term Ecological Research sites (United States, summer only); F McMurdo Station (United States, year-round); and G Scott Base (New Zealand, yearround). The map shading along Victoria Land represents the approximate boundaries between the open-water, fast-ice and iceshelf zones that reflect the increasing duration of ice cover over the ocean and decreasing availability of water vapor.

Latitudinal Gradient Project (http://www.lgp.aq/) along the coast of Victoria Land, Antarctica, with emphasis on the marine research.

The Victoria Land coastal biome is defined by the complex of adjacent terrestrial and marine ecosystems that occupy permanently ice-free oases and outcrops on land, as well as periodically openwater and ice-covered habitats in the ocean, from approximately $72^{\circ} \mathrm{S}$ to $86^{\circ} \mathrm{S}$ (Fig. 1). Across this latitudinal gradient, ecosystems are operating at the liquid margin of life where climate changes have an amplified impact on the phases of water. This latitudinal gradient parallels the predominant trend of ice-

sheet expansion and retreat associated with global climate changes (Conway et al., 1999). Consequently, in an experimental context, Victoria Land provides a spatial gradient for evaluating environmental and ecosystem variability that otherwise would be recognised only through time. These features frame the rationale and activities in the Victoria Land Latitudinal Gradient Project that began emerging in 1999 under the coordination of Antarctica New Zealand, the Italian Programma Nazionale di Richerche in Antartide and the United States Antarctic Programme (Berkman and Everett, 2001).

The Latitudinal Gradient Project along Victoria Land is complemented by the Regional Sensitivity to Climate Change programme that is being sponsored by the Scientific Committee on Antarctic Research to assess terrestrial ecosystem responses to environmental and climate changes in the south polar region (http://www.riscc.aq). Together, the marine and terrestrial components of these latitudinal gradient research programmes are contributing to our understanding of species, community and ecosystem responses to global changes (Walther et al., 2002).

\section{RESEARCH FRAMEWORK FOR THE LATITUDINAL GRADIENT PROJECT}

The climate-driven dynamics and coupling of marine and terrestrial environments and ecosystems along Victoria Land are influenced strongly by different forms of ice (Table 1). As the solid phase of water, ice represents aspects of the hydrological cycle that impact: moisture exchanges; marine, freshwater and terrestrial ecosystem dynamics; and the basic availability of liquid water for terrestrial life. In particular, sea ice has a pronounced influence on the dynamics of marine and terrestrial ecosystems as one of the most integrated natural phenomena in the Antarctic region. Because of diverse hydrological, glaciological, oceanographic and meteorological feedbacks, there also are numerous gradients and thresholds in the types and distribu-

TABLE 1. - Ice along Victoria Land, Antarctica.

Habitats Types of Ice

Marine

Freshwater Terrestrial snow, sea ice, ice tongues, ice shelves, icebergs, anchor ice snow, lake ice, glaciers, permafrost snow, glaciers, permafrost, land ice, ice sheets 
tions of sea ice along Victoria Land today. For example, from west McMurdo Sound to the Drygalski Ice Tongue there is landfast sea ice that is associated with supercooled water moving northward from under the Ross Ice Shelf. In contrast, annual sea ice occurs in east McMurdo Sound and north of the Drygalski Ice Tongue, which also influences the open-water region of the Terra Nova Bay polynya. These features of ice formed the basis for the following collaboration topics in the Victoria Land Latitudinal Gradient Project:

Collaboration Topic 1: Environmental thresholds across the latitudinal gradient of Victoria Land (e.g. continental shelf break, Drygalski Ice Tongue and Ross Ice Shelf) have a significant influence on the complexity of associated marine and terrestrial ecosystems.

Collaboration Topic 2: Across the latitudinal gradient of the Victoria Land system, ecological responses to land-air-sea interactions associated with climatic variability are amplified by ice (Table 1) and the availability of liquid water.

Collaboration Topic 3: Marine-terrestrial coupling across the Victoria Land system varies over time and space in relation to transfers of mass (sediments, salts, gases, water, nutrients, organic matter and organisms), momentum (currents and winds) and energy (latent heat).

In effect, collaborative topics \#1 and \#2 provide alternative hypotheses that could be tested and modelled to interpret ecosystem and environmental variability along the latitudinal gradient of Victoria Land (Fig. 2). In addition, the ice dynamics along Victoria Land lead to the identification of three zones (Fig. 1) that are distinguished by the duration of ice cover in the ocean:

Open-Water Zone: annual sea-ice retreat and exposure of open water.

Fast-Ice Zone: episodic retreat of sea ice every few years.

Ice-Shelf Zone: continuous ice coverage on the ocean over millennia.

\section{MARINE ECOSYSTEM FEATURES ALONG VICTORIA LAND}

Marine ecosystems along Victoria Land are known to vary across the latitudinal gradient in

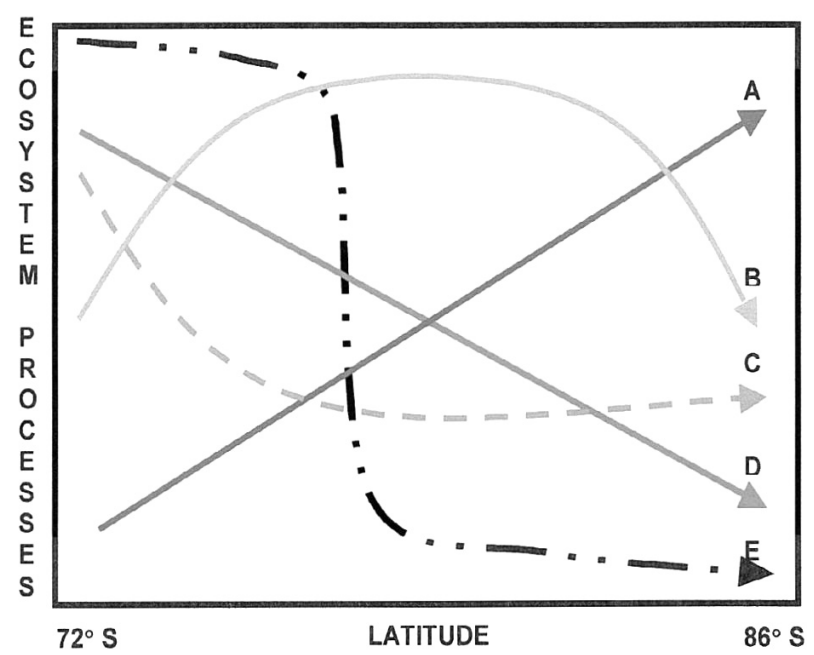

FIG. 2. - Alternative explanations for the variability in comparable ecosystem processes in marine, freshwater and terrestrial habitats (Table 1) across the latitudinal gradient of Victoria Land, Antarctica: A and D (linear ecosystem changes associated with environmental phenomena such as solar radiation and photo-periods); and $\mathbf{B}, \mathbf{C}$ and $\mathbf{E}$ (non-linear ecosystem changes associated with environmental phenomena such as the number of freeze-thaw cycles and ice-tongue thresholds). From Berkman and Everett (2001).

terms of maximum sea-surface temperatures; seaice extent, productivity and species assemblages. Oceanographic surveys indicate that maximum seasurface temperatures are greater than $2^{\circ} \mathrm{C}$ north of the Drygalski Ice Tongue but are less than $0^{\circ} \mathrm{C}$ in McMurdo Sound to the south (Jacobs and Giulivi, 1998). Sea-ice along the coast of Victoria Land also varies with current patterns, harbours and embayments, katabatic wind regimes and ice-tongues. Generally, in west McMurdo Sound there is multiyear sea ice, which can increase in thickness to nearly 6 metres depth over periods longer than six years. On the other end of the extreme are open-water areas, like the Terra Nova Bay and Ross Sea polynyas. Responding to their environments, marine species along Victoria Land may vary in terms of their distributions and abundances; life history patterns, morphologies and energetics; and biochemical and physiological adaptations.

Most of our understanding about benthic marine communities along Victoria Land is limited in geographic scope to McMurdo Sound (which has been extensively surveyed by the United States and New Zealand Antarctic programmes) and Terra Nova Bay (which has been extensively surveyed by the Programma Nazionale di Ricerche in Antartide). It is known that benthic algae are luxuriant in the Terra Nova Bay region, with vibrant stands at depths of less than 20 metres, whereas they are virtually absent in most areas in west McMurdo Sound. 
These benthic macroalgae also include extensive coverage of coralline red algae on virtually all rocks in shallow water in the Terra Nova Bay region while they are rare in McMurdo Sound. This distribution of calcareous benthic algae is, in part, related to the warmer sea-surface temperatures and decreased solubility of calcium carbonate in the Terra Nova Bay region. Current New Zealand research is utilising these natural gradients in environmental conditions and productivity along the latitudinal gradient encompassed by the Victoria Land Coast; to investigate how variation in sea ice cover and primary production sources effects the structural and functional biodiversity of coastal benthic ecosystems. Climaterelated environmental processes will influence the community dynamics and spatial structure of benthic populations, and hence there is potential for regional climate variability to impact ecosystem structure and function.

Among the benthic macroinvertebrates, species like the circum-Antarctic scallop (Adamussium colbecki) provide experimental templates for comparing and contrasting environmental conditions between habitats. For example, as in the distribution of coralline algae, Adamussium shells are significantly thicker in Terra Nova Bay than in McMurdo Sound, with stable isotope signatures that further reflect the relative seawater temperatures and production levels between these regions (Berkman et al., 2004). There are also indications that Adamussium are releasing their gametes later in the austral summer and producing larger planktonic larvae in Terra Nova Bay than in McMurdo Sound (Chiantore et al., 2000). In addition, there are marked differences in the abundance and depth distributions of both Adamussium and Sterechinus neumayeri (urchin) between McMurdo Sound and Terra Nova Bay (Chiantore et al., 1998, 2001).

At the upper trophic levels, fish species have been an important research focus along Victoria Land because of their accessibility and utility for assessing adaptive responses to environmental variability. Fish trawls have provided important baselines for characterizing marine community structures, diversities and distributions in relation to oceanographic conditions along Victoria Land, with additional sites proposed from south to north (Eastman and Hubold 1999):

Erebus Basin as a baseline for high-latitude deepwater locality.

Sponge beds as sites of topographic and trophic complexity leading to high fish diversity.

Crary or Mawson banks as sites of high diversity surrounded by deep water areas.

Drygalski Trough as site of deepest and largest inner shelf depression in the Ross Sea.

Cape Adare as a continental shelf transition zone.

Iselin Seamount as a site of faunal transition and dispersal into the Ross Sea.

Antarctic fish are unique among vertebrates as the only fauna to have species (family Channichthyidae) without haemoglobin in their blood. Glycoprotein antifreezes, as well as other biochemical and physiological adaptations, reflect additional adaptive responses at the extreme of cold seawater temperatures. Relatively subtle increases in seawater temperatures could alter the physiological and biochemical processes among Antarctic fish faunas. Moreover, seawater temperature increases could lead to the incursion of species not generally found in the high latitudes that would further alter fish community compositions, interactions and dynamics.

Environmental conditions and suitable habitats similarly influence the distribution of avian faunas in the Ross Sea region. For example, the distribution of penguin rookeries is closely coupled with sea-ice coverage because of their required access to openwater areas where they forage. Today, the largest Adélie penguin (Pygoscelis adelie) rookery in Antarctica occurs in Cape Adare, with most southern rookeries along Victoria Land in the vicinity east of McMurdo Sound, where there is direct coastal access to open water every year. Guano deposits from these penguin rookeries, which include remains of their prey as well as organic materials for radiocarbon dating (Emslie et al., 2003), provide information for assessing their past distributions and palaeo-environmental conditions.

Among the marine mammals, the southernmost seal species on Earth is the Weddell seal (Leptonychotes weddellii). This seal species, which is adapted to fast-ice environments, occurs throughout the coastal region of Victoria Land but with larger abundances in areas where there are cracks through the sea-ice and there is underwater access. In connection with the Antarctic Pack Ice Seal (APIS) programme in the 2000 austral summer, monitoring of seal populations revealed an apparent latitudinal gradient in crabeater seal (Lobodon carcinophagus) density along four north-south transect lines in the Ross Sea. Long-term population measurements of seal populations in McMurdo Sound further reveal 
potential connections with inter-annual and interdecadal oscillations in the global atmosphere.

The corresponding history of ecosystem development along Victoria Land, which only became possible after habitats were no longer covered by ice sheets, is reflected by Holocene deposits in marine sediments, emerged beaches, terrestrial lakes, terrestrial ecosystems, penguin rookeries and ice cores. In particular, beginning around 6000 years ago, the Ross Sea region entered a new phase in ecosystem dynamics in conjunction with global climate conditions and local environmental changes in sea-ice coverage (Emslie et al., 2003). These ecosystem changes are reflected by the geochemistry of the ice sheet in the terrestrial zone, occurrence of marine species in the coastal transition zone and deposition of phytoplankton species in the marine zone along Victoria Land (Berkman et al., 2004). This period, from the mid-Holocene to the present, is most relevant to understanding ecosystem dynamics today.

\section{LATITUDINAL GRADIENT RESEARCH CRUISES IN THE ROSS SEA IN 2004}

The first ship-based marine campaigns in the framework of the Victoria Land Latitudinal Gradient Project were conducted in early 2004 on board the
R/V "Italica" (3-22 February) and R/V "Tangaroa" (3 February - 7 March). The principal sites investigated by the R/V "Italica" were Cape Adare, Cape Hallett, Coulman Island, and Cape Russell. Contemporaneously to this Italian expedition, a 'sister' cruise by the R/V "Tangaroa" from New Zealand explored the marine benthic biodiversity and mapped the seabed of the northwestern Ross Sea and Balleny Islands.

The R/V "Italica" cruise involved extensive sampling in deeper environments along the Victoria Land Coast to enable both latitudinal and depthrelated comparisons of the benthic communities and habitats. At each location, sampling was conducted along along depth gradients, with stations at nominal depths of 500, 400, 300, 200 and $100 \mathrm{~m}$. Preliminary benthic community characteristics are shown in Table 2.

In addition, scientists from the Seafloor Mapping Lab from California State University Monterey Bay performed high-resolution acoustic remote sensing (multibeam and sidescan sonar) along with remotely operated vehicle video mapping. All sites were investigated with these remote survey tools, with the exception of Coulman Island, where a heavy sea-ice cover extended from shore out over the $400 \mathrm{~m}$ depth contour (Table 3 ). The multibeam imagery revealed extensive ice scouring that varied with location, depth and expo-

TABLE 2. - Benthic community characteristics along Victoria Land, Antarctica, from the 2004 R/V "Italica" cruise (Fig. 3).

\begin{tabular}{|c|c|c|c|c|c|c|c|c|}
\hline Site & $\begin{array}{l}\text { Latitude } \\
\text { (S) }\end{array}$ & $\begin{array}{l}\text { Longitude } \\
\text { (E) }\end{array}$ & Station & $\begin{array}{l}\text { Depth } \\
(\mathrm{m})\end{array}$ & Substrate & Assemblage & $\begin{array}{c}\text { Relative } \\
\text { Biodiversity }\end{array}$ & $\begin{array}{r}\text { Percent Dry } \\
\text { Weight } \\
\text { (mainly } \\
\mathrm{CaCO}_{3} \text { ) }\end{array}$ \\
\hline Cape Adare & $71^{\circ} 15.5^{\prime}$ & $170^{\circ} 42.2^{\prime}$ & A1 & $515-476$ & sand, cobbles & Ophiuroid community & LOW & 69 \\
\hline Cape Adare & $71^{\circ} 17.3^{\prime}$ & $170^{\circ} 39.2^{\prime}$ & A2 & $430-421$ & sand & Stylasterinids & LOW & \\
\hline Cape Adare & $71^{\circ} 18.7^{\prime}$ & $170^{\circ} 33.5^{\prime}$ & A3 & $312-305$ & sand, rocks & Stylasterinids & MEDIUM & 36 \\
\hline Cape Adare & $71^{\circ} 18.4^{\prime}$ & $170^{\circ} 28.9^{\prime}$ & A4 & $235-223$ & sand, cobbles & Tube-like ascidians & HIGH & 47 \\
\hline Cape Adare & $71^{\circ} 18.8^{\prime}$ & $170^{\circ} 26.7^{\prime}$ & A5 & $139-124$ & sand, cobbles & Foliose ascidians & $\mathrm{HIGH}$ & 41 \\
\hline Coulman I. & $73^{\circ} 24.5^{\prime}$ & $170^{\circ} 23.2^{\prime}$ & $\mathrm{C} 1$ & $480-474$ & mud, cobbles & Ophiuroid community & HIGH & 94 \\
\hline Coulman I. & $73^{\circ} 22.7^{\prime}$ & $170^{\circ} 06.9^{\prime}$ & $\mathrm{C} 2$ & $410-372$ & mud, cobbles & Pterobranchia community & HIGH & 85 \\
\hline Cape Hallett in & $72^{\circ} 16.7^{\prime}$ & $170^{\circ} 09.8$ & $\mathrm{H}$-in 2 & $408-391$ & mud, cobbles & Gorgonian community & MEDIUM & 79 \\
\hline Cape Hallett in & $72^{\circ} 17.2^{\prime}$ & $170^{\circ} 12.3^{\prime}$ & $\mathrm{H}$-in 3 & $369-312$ & mud, sand, cobbles & Tube-like ascidians & HIGH & 35 \\
\hline Cape Hallett in & $72^{\circ} 17.7$ & $170^{\circ} 12.2^{\prime}$ & $\mathrm{H}$-in 4 & $266-228$ & mud, sand & Ophiuroids & LOW & 43 \\
\hline Cape Hallett in & $72^{\circ} 17.1^{\prime}$ & $170^{\circ} 14.0^{\prime}$ & $\mathrm{H}$-in 4bis & 196 & & Botriform ascidians & HIGH & \\
\hline Cape Hallett in & $72^{\circ} 17.6$ & $170^{\circ} 12.8^{\prime}$ & $\mathrm{H}$-in 4tris & $156-152$ & mud & Polychaetes & LOW & \\
\hline Cape Hallett in & $72^{\circ} 17.2^{\prime}$ & $170^{\circ} 17.9^{\prime}$ & $\mathrm{H}$-in 5 & 84 & & Botriform ascidians & HIGH & 70 \\
\hline Cape Hallett out & $72^{\circ} 15.5^{\prime}$ & $170^{\circ} 28.3$ & Hout 1 & $537-475$ & mud, cobbles & Bryozoans + gorgonians & LOW & \\
\hline Cape Hallett out & $72^{\circ} 17.1$, & $170^{\circ} 29.9^{\prime}$ & H-out 2 & $388-353$ & mud, sand & Flustridae & $\mathrm{HIGH}$ & 77 \\
\hline Cape Hallett out & $72^{\circ} 16.3^{\prime}$ & $170^{\circ} 24.9^{\prime}$ & Hout 2 bis & $337-332$ & cobbles & Bryozoans & $\mathrm{HIGH}$ & \\
\hline Cape Hallett out & $72^{\circ} 17.5^{\prime}$ & $170^{\circ} 26.1^{\prime}$ & Hout 3 & $289-246$ & sand, cobbles & Bryozoans & HIGH & \\
\hline Cape Hallett out & $72^{\circ} 17.2^{\prime}$ & $170^{\circ} 23.9^{\prime}$ & Hout 4 & $235-195$ & cobbles & Bryozoans (Celleporinidae) & $\mathrm{HIGH}$ & 84 \\
\hline Cape Hallett out & $72^{\circ} 16.9^{\prime}$ & $170^{\circ} 17.0^{\prime}$ & Hout 5 & $106-103$ & sand, cobbles & Mixed community & HIGH & 61 \\
\hline Cape Russell & $74^{\circ} 49.0^{\prime}$ & $164^{\circ} 18.1^{\prime}$ & R 2 & 364 & & Bryozoans & MEDIUM & 71 \\
\hline Cape Russell & $74^{\circ} 49.8^{\prime}$ & $164^{\circ} 12.9^{\prime}$ & R 3 & $330-307$ & sand, cobbles & Gorgonians & HIGH & 64 \\
\hline Cape Russell & $74^{\circ} 50.2^{\prime}$ & $164^{\circ} 05.5^{\prime}$ & R 4 & $216-174$ & sand, cobbles & Bryozoans and Pterobranchia & MEDIUM & 74 \\
\hline Cape Russell & $74^{\circ} 49.9^{\prime}$ & $164^{\circ} 05.3^{\prime}$ & $\mathrm{R} 4 \mathrm{bis}$ & $156-135$ & sand, cobbles & Gorgonians & MEDIUM & \\
\hline Terra Nova Bay & $74^{\circ} 43.6^{\prime}$ & $164^{\circ} 13.6^{\prime}$ & SMN & $366-363$ & sand, cobbles & Polychaetes & LOW & 75 \\
\hline
\end{tabular}


TABLE 3. - Multibeam surveys along Victoria Land, Antarctica, from the 2004 R/V "Italica" cruise (Fig. 3).

\begin{tabular}{lcccr}
\hline Site & $\begin{array}{c}\text { Survey } \\
\text { lines }\end{array}$ & $\begin{array}{c}\text { Linear } \\
\text { distance }(\mathrm{km})\end{array}$ & $\begin{array}{c}\text { Total area } \\
\left(\mathrm{km}^{2}\right)\end{array}$ & $\begin{array}{r}\text { Total } \\
\text { soundings }\end{array}$ \\
\hline Cape Hallett & 92 & 197.0 & 37.27 & $20,418,059$ \\
Cape Adare & 27 & 96.9 & 23.78 & $8,389,464$ \\
Cape Russell & 22 & 72.6 & 11.30 & $7,564,900$ \\
TOTAL & 141 & 366.5 & 72.35 & $36,372,423$ \\
\hline
\end{tabular}

sure. A wide variety of ice disturbance features were clearly visible from shallow scrapes less than $1 \mathrm{~m}$ deep to broad gouges $100 \mathrm{~m}$ wide with more than 8 metres of vertical relief from trough to berm (Fig. 3).

In general, the preliminary multibeam results reveal a subtidal landscape dominated by a mosaic of disturbance patches stratified by depth and in various stages of recovery. Habitats at depths of 200$300 \mathrm{~m}$ and unprotected by topographic highs are exposed to the massive impact of tabular icebergs hundreds to thousands of metres in horizontal dimensions that come from the $300 \mathrm{~m}$ thick Ross Ice Shelf. The scours made by these giants are unmistakable due to the depth range in which they occur, and the characteristically broad and extremely flat "road-like" appearance of the features. In the 40-150 $\mathrm{m}$ depth range, the scours tend to be narrower, carved by more pointed ice keels ending in a terminal pit.

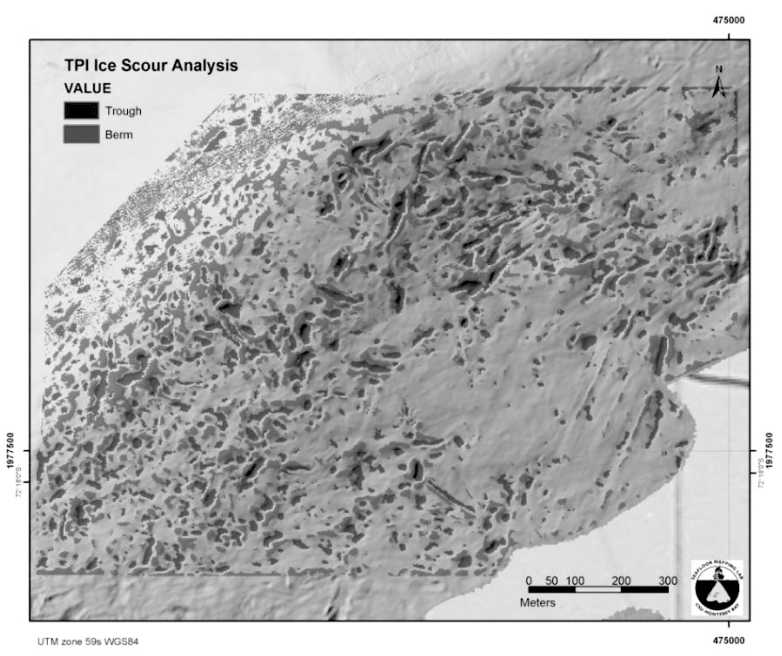

FIG. 3. - Representative shaded relief multibeam image of the marine bottom in the Cape Hallett area along the Victoria Land Coast of Antarctica in the vicinity of $72^{\circ} 18^{\prime} \mathrm{S}$ and $170^{\circ} 16^{\prime} \mathrm{E}$ at 40 $50 \mathrm{~m}$ depth. Topographic Position Index (TPI) analysis was applied to a $2 \mathrm{~m}$ Digital Elevation Model (DEM) grid of the same area and "tuned" to detect troughs (black) and berms (dark gray). These results indicate that $28.95 \%$ (12.72\% troughs and $16.23 \%$ berms) of the $1,376,328 \mathrm{~m}^{2}$ area was scoured by icebergs. The multibeam surveys on the R/V "Italica" cruise were produced by the Seafloor Mapping Lab from California State University Monterey Bay.
Antarctic benthic communities are strongly influenced by iceberg disturbance (Gutt, 2001), but to date there have been few investigations on the spatial extent to which this occurs (or its frequency) in the coastal Ross Sea region (Lenihan and Oliver, 1995). Preliminary investigations of shallow water benthos $(<30 \mathrm{~m})$ on the R/V "Italica" cruise indicated striking differences in abundance and diversity of macroalgae, and biogenic habitats in the northwestern Ross Sea compared with McMurdo Sound. This cruise has provided valuable insights into the relative importance of different environmental variables that structure communities in the coastal Ross Sea region and how they might change with latitude (e.g. iceberg disturbance, sea ice cover, light regime and primary production sources), which will be assessed with future sampling.

A major objective of the $R / V$ Tangaroa voyage was to collect information on the diversity of benthic macroinvertebrate and fish communities, and habitat types, along the northern Victoria Land coast and around the Balleny Islands. Phytoplankton productivity of the overlying water, physical disturbance of the bottom by icebergs, and the complexity of habitat-forming species in affecting faunal distribution and biodiversity also were investigated. Together, these data provide baseline information to assess ecosystem and environmental impacts from the growing human presence in Antarctica.

Five across-shelf (generally aligned SW-NE) transects from the $50 \mathrm{~m}$ bottom depth to the shelf edge (approx. $750 \mathrm{~m}$ ) were multibeamed to establish bathymetry, and benthic sampling was conducted within three depth strata $(750-500,500$ $250,250-50 \mathrm{~m})$. The transects ran roughly perpendicular to the shoreline and were evenly spread from Cape Adare down to Cape Hallett. A wide variety of gear types was deployed (bottom trawl, beam trawl, epibenthic sled, and grabs) to sample different assemblages and provide a much greater appreciation of macrofaunal diversity than would be gained from using just one or two types of gear (e.g. Arntz, 1999). Camera deployment further added to information on the nature of benthic habitats, and information on sediment characteristics (e.g. particle size, organic carbon, and chlorophyll content) was also collected. Preliminary results indicate marked differences in species composition between the Ross Sea and Balleny Island locations. In addition, the sessile fauna was dominated by sea squirts and corals in offshore (deeper) areas, and by sponges inshore. 


\section{CONCLUSIONS}

Research along the Victoria Land Coast goes back to the end of the $18^{\text {th }}$ century, with the first winter-over expedition in Antarctica (Borchgrevink, 1901). The 2004 research cruises of the R/V "Italica" and R/V "Tangaroa" are part of this rich history.

The Latitudinal Gradient Project along Victoria Land provides an interdisciplinary umbrella for compiling and integrating data, maps, figures, tables, geographic information systems and publications that have been collected for more than a century regarding the components, dynamics and chronologies of terrestrial and marine ecosystems and environments over diverse time and space scales in Antarctica. These interdisciplinary data involve the geology, limnology, meteorology, glaciology, oceanography and ecology associated with the southernmost ecosystems on Earth. For the future, this research on the coupling and dynamics of marine and terrestrial ecosystems along Victoria Land provides a unique framework for assessing latitudinal shifts in 'sentinel' environmental transition zones (Fig. 1), as a global barometer that reflects climate dynamics.

\section{ACKNOWLEDGEMENTS}

Marine research activities and development of the latitudinal gradient project along Victoria Land, Antarctica, have been jointly supported by Antarctica New Zealand, the New Zealand Ministry of Fisheries, the Programma Nazionale di Richerche in Antartide and the United States Antarctic Programme.

\section{REFERENCES}

Arntz, W.E. - 1999. Magellan-Antarctic: ecosystems that drifted apart. Summary review. Sci. Mar., 63(Suppl. 1): 503-511.

Berkman, P.A. - 2002. Science into policy: Global lessons from Antarctica. Academic Press, San Diego.

Berkman, P.A. and L.R. Everett (eds.). - 2001. Latitudinal ecosystem (LAT-ECO) responses to climate across Victoria Land, Antarctica. Report of a National Science Foundation Workshop. Byrd Polar Research Center Report No. 20, The Ohio State University, Columbus.

Berkman, P.A., R. Cattaneo-Vietti, M. Chiantore and C. HowardWilliams. - 2004. Polar emergence and the influence of increased sea-ice extent on the Cenozoic biogeography of pectinid molluscs in Antarctic coastal areas. Deep-Sea Res., 11: 1839-1855.

Borchgrevink, C.E. - 1901. First on the Antarctic continent. Being an account of the British Antarctic expedition 1898-1900. George Newnes, London.

Chiantore, M., R. Cattaneo-Vietti, P. Povero and G. Albertelli. 2000. The population structure and ecology of the Antarctic scallop Adamussium colbecki in Terra Nova Bay. In: F.M. Faranda, L. Guglielmo and A. Ianora (eds.), Ross Sea ecology: Italian Antarctic expeditions (1986-1995), pp. 563-573. Springer, Berlin.

Chiantore, M., R. Cattaneo-Vietti, G. Albertelli, C. Misic and M. Fabiano. - 1998. Role of filtering and biodeposition by Adamussium colbecki in circulation of organic matter in Terra Nova Bay (Ross Sea, Antarctica). J. Marine. Syst., 17: 411-424.

Chiantore M., R. Cattaneo-Vietti, P.A. Berkman, M. Nigro, M. Vacchi, S. Schiaparelli and G. Albertelli. - 2001. Antarctic scallop (Adamussium colbecki) spatial population variability along the Victoria Land Coast, Antarctica. Polar Biol., 23: 753-758.

Conway, H., B.L. Hall, G.H. Denton, A.M. Gades and E.D. Waddington. - 1999. Past and future grounding-line retreat of the West Antarctic ice sheet. Science, 286, 280-283.

Eastman, J.T. and G. Hubold. - 1999. The fish fauna of the Ross Sea, Antarctica. Antarct. Sci., 11: 293-304.

Emslie, S.D., P.A. Berkman, D.G. Ainley, L. Coats and M. Polito. 2003. Late-Holocene initiation of ice-free ecosystems in the southern Ross Sea, Antarctica. Mar. Ecol. Prog. Ser., 262: 19-25.

Gutt, J. - 2001. On the direct impact of ice on marine benthic communities: a review. Polar Biol., 24: 553-564.

Jacobs, S.S. and C.F. Giulivi. - 1998. Interannual ocean and sea ice variability in the Ross Sea. In: S.S. Jacobs and R.F. Weiss (eds.), Ocean, ice and atmosphere: Interactions at the Antarctic continental margin, pp. 135-150. Antarctic Research Series 75. American Geophysical Union, Washington, D.C.

Lenihan, H.S. and J.S. Oliver. - 1995. Anthropgenic and natural disturbances to marine benthic communities in Antarctica. Ecol. Appl., 5: 311-326.

Walther, G.-R., E. Post, P. Convey, A. Menzel, C. Parmesan, T.J.C. Beebee, J.-M. Froomentin, O. Hoegh-Guldberg and F. Bairlein. - 2002. Ecological responses to recent climate change. Nature, 416: 389-395. 
